\title{
KEBAHAGIAAN DAN GENDER: TINJAUAN KRITIS TENTANG MAKNA KEBAHAGIAAN DITINJAU DARI PERSPEKTIF GENDER
}

\author{
Riza Amaliya \\ rz.amaliya@gmail.com \\ Magister Sains Psikologi \\ Konsentrasi Psikologi Industri dan Organisasi \\ Program Pascasarjana Universitas Muhammadiyah Malang
}

\begin{abstract}
Abstrak - Sepanjang hidupnya manusia selalu berupaya mencari kebahagiaan (happiness). Psikologi positif, yang merupakan salah satu cabang dari psikologi membahas tentang upaya manusia untuk mencapai kebahagiaan. Kebahagiaan bisa dilihat dari berbagai sudut pandang. Pembahasan kali ini merupakan tinjauan teoritis yang difokuskan pada kebahagiaan pada level subjektif atau subjective well being, khususnya dilihat dari perbedaan gender.
\end{abstract}

Kata Kunci: Kebahagian, Gender, Well Being

PSIKOISLAMIKA. Jurnal Psikologi Islam (JPI) copyright @ 2015 Pusat Penelitan dan Layanan Psikologi. Volume 12. Nomor 2, Tahun 2015

\section{PENDAHULUAN}

Psikologi positif sebagai kajian baru dalam ranah psikologi berupaya membawa pemahaman fungsi - fungsi manusia tidak hanya dari sisi negatif, seperti halnya yang telah terjadi beberapa dekade yang lalu. Namun ada sebuah anggapan bahwa psikologi positif sebenarnya bukan hal yang baru, karena bidang pembahasannya sudah pernah dikaji oleh Psikologi humanistik. Sayangnya, pada saat itu psikologi humanistik tidak mendasarkan teorinya pada penilitian yang bersifat empiris (Seligman, Csikszenimihalyi, 2000). Terlepas dari hal itu, psikologi positif berupaya mengubah paradigma negatif yang selama ini dianut oleh bidang psikologi, menjadi positif.

Penelusuran paradigma psikologi positif, sebenarnya jauh sebelum ilmu psikologi positif itu muncul. Paradigma yang menyatakan upaya untuk menggapai 'The good life'. Di era Yunani, Aristoteles mengungkapkan bahwa pencapaian kebaikan tertinggi oleh manusia adalah eudaimonia atau happiness (kebahagiaan) (Hefferon, 2011).
Namun penggunaan terminologi happiness lebih banyak digunakan untuk menjelaskan hedonic yang lebih memiliki pengertian kepercayaan yang dimiliki seseorang bahwa sebuah kesenangan yang dirasakan, dikarenakan memperoleh sesuatu yang diinginkan (Waterman, 1993).

Prinsip penanganan psikologi positif adalah dengan upaya pencegahan sebelum terjadinya masalah (Seligman, Csikszenimihalyi 2000). Penerapan psikologi positif terdiri dari aspek : 1) Aspek psikologi positif dari sudut pandang subjektif, misalnya kepuasan hidup, cinta, kebahagiaan. 2) aspek psikologi positif pada level individu yang terfokus pada karakter positif individu, atau tingkah laku positif yang ditunjukkan oleh manusia, misalnya kebijaksanaan, kejujuran, kemampuan mengelola potensi kreatif untuk mencapai kesuksesan. 3) aspek psikologi positif yang ditinjau dari kelompok atau level masyarakat, yang berfokus pada perkembangan, misalnya menumbuhkan keluarga yang sehat, kajian tentang lingkungan kerja yang sehat (Compton, Hoffman, 2013). Berdasarkan aspek penerapan 
psikologi positif tersebut, makalah ini mencoba mengkaji tentang perbedaan penerapan psikologi positif pada level subjektif dilihat dari kebahagiaan, yang dibedakan berdasarkan gender. Walaupun telah banyak diketahui bahwa ada perbedaan yang mendasar antara pria dan wanita, namun keduanya memiliki kesempatan yang sama untuk menyatakan bahwa mereka merasa "sangat senang" dan "puas" terhadap hidup mereka (Myers, 1999).

\section{KERANGKA KERJA TOERITIK}

\section{Kebahagiaan}

Pembahasan makalah ini berfokus pada kebahagiaan level subjektif (subjective level), dilihat dari sudut pandang perbedaan gender. Perspektif subjektif dianggap demokratis dalam memandang kebahagiaan yang dialami individu, karena individu diberikan kesempatan untuk memaknai dan merasakan kehidupan yang dialaminya (Synder dan Lopez, 2002).

Menurut Bradburn, Kebahagiaan (happiness) merupakan istilah yang terkadang digunakan bergantian dengan subjective well being, yang terdiri dari 2 dimensi yakni perasaan positif dan perasaan negatif. Dari sudut pandang ini, yang dikatakan seseorang dengan psychological well being apabila terdapat dominasi perasaan positif dibandingkan yang negatif (Gurel, 2009).

Tiga komponen dasar dalam subjective well being yaitu life satisfaction (kepuasan hidup), positive affect (perasaan positif) dan negative affect (perasaan negatif). Perasaan positif adalah frekuensi dan intensitas dari emosi menyenangkan seperti happiness (kebahagiaan) dan joy (keriangan). Sedangkan emosi negative adalah frekuensi dan intensitas dari emosi tidak menyenangkan seperti kesedihan dan kekhawatiran (Baumgardner,Crothers,2010:21).

Pemahaman tentang happiness dibagi menjadi 3 elemen yaitu ; positive emotion atau emosi positif, kemudian setelah postif emosi didapat selanjutnya internalisasi atau engagement /keterikatan terhadap emosi itu. Lalu yang ketiga adalah menarik makna kehidupan, melakukan sesuatu kemudian memberikan sesuatu yang lebih besar dari apa yang telah dialami (Seligman, 2010:233).

\section{Sudut Pandang Kebahagiaan}

Terdapat dua sudut pandang dalam melihat kebahagiaan, yakni hedonic dan Eudaimonic. Pada sudut pandang hedonic disebutkan bahwa happiness atau kebahagiaan adalah kesimpulan secara umum yang dilakukan individu terkait dengan emosi positif dan negative serta kepuasan hidupnya. Seseorang yang memiliki kelimpahan emosi yang positif dan sedikit emosi negatif, serta puas terhadap kehidupannya, didefinisikan sebagai happy. Sedangkan menurut sudut pandang Eudaimonic disebutkan bahwa well being adalah postif atau fungsi yang optimal dan pemenuhan terhadap kebutuhan dasar dan potensi diri. Happy person adalah seseorang yang memiliki ciri, seseorang yang bekerja keras untuk melaksanakan potensi dirinya supaya dapat mencapai potensi diri yang penuh, kompeten dan memiliki kesehatan psikologis (Baumgardner,Crothers, 2010).

Apabila perasaan yang baik dapat meniadakan perasaan buruk pada satu waktu, nantinya pada satu waktu salah satu perasaan tersebut ada yang meningkat dan di saat yang lain akan menurun. Seseorang yang kerap mengalami perasaan yang baik, kemungkinan akan menglami perasaan yang buruk juga. Pada beberapa orang, ada yang mengalami perasaan yang sangat menggebu - gebu, dimana perasaan itu saling bergantian dengan perasaan yang tidak menyenangkan (Myers dan Diener, 1995:11).

\section{DISKUSI}

\section{Perbedaan gender dalam emosi}

Terdapat dua macam emosi yaitu emosi positif dan emosi negatif. Berdasarkan emosi tersebut, terdapat perbedaan antara wanita dan pria dalam mengalami kedua macam emosi tersebut. Berikut ini table yang menunjukkan perbedaan emosi yang dialami wanita dan pria (Baumgardner dan Crothers, 2010:86). 


\begin{tabular}{|c|c|c|}
\hline \multirow{2}{*}{$\begin{array}{l}\text { Jenis } \\
\text { Emosi }\end{array}$} & \multicolumn{2}{|r|}{ Gender } \\
\hline & Wanita & Pria \\
\hline Negatif & $\begin{array}{l}\text { Lebih sering mengalami emosi negatif, } \\
\text { khususnya internalizing disorder, } \\
\text { yaitu mengalami lebih sering dalam } \\
\text { dirinya sendiri emosi negatif. Wanita } \\
\text { tidak hanya mengalami emosi,namun } \\
\text { juga mengekspresikan emosi tersebut, } \\
\text { dibandingkan pria. Emosi-emosi } \\
\text { yang kerap dialami wanita yaitu } \\
\text { sedih,takut,cemas, malu dan rasa } \\
\text { bersalah. }\end{array}$ & $\begin{array}{l}\text { Pria mengalami externalizing disorder yaitu emosi yang } \\
\text { ditujukan pada objek,situasi dan orang-orang. Pria } \\
\text { terlibat dalam penggunaan obat-obatan terlarang,dan } \\
\text { sebagainya. Pria secara fisik lebih agresif dibandingkan } \\
\text { wanita. }\end{array}$ \\
\hline Positif & $\begin{array}{l}\text { Wanita lebih banyak mengalami emo } \\
\text { lain menyebutkan bahwa tidak ada } \\
\text { wanita dan pria. }\end{array}$ & $\begin{array}{l}\text { si positif dibandingkan pria. Namun beberapa penelitian } \\
\text { perbedaan happiness atau kebahagiaan yang dialami }\end{array}$ \\
\hline
\end{tabular}

Perbedaan antara pria dan wanita dalam memandang kebahagiaan, lebih dikarenakan perbedaan peran sosial yang dialaminya, yang kemudian berdampak langsung kepada pengalaman dan sikap-sikap yang dimilikinya. Termasuk didalamnya dalam perbedaan cara pria dan wanita untuk mengungkapkan emosi. Wanita dalam masyarakat merupakan individu yang diplot sebagai seorang yang dituntut menunjukkan emosi,karena banyak berhubungan dengan pengasuhan, seperti; menjadi ibu,menjadi istri, menjalani pekerjaan sebagai guru, perawat. Sedangkan peran pria tidak banyak yang ditekankan pada penggunaan emosi. Sehingga wanita dianggap lebih dapat mengekspresikan emosinya, memiliki emosi yang labil dan dapat menunjukkan emosi yang sedang dirasakannya. Berbeda dengan pria yang lebih memiliki kestabilan emosi, emosinya tidak mudah dipicu (Wood, Wendy, Rhodes, Whelan,M, 1989).

\section{Penelitian yang Membahas Tentang Perbedaan Kebahagiaan Pada Pria dan Wanita.}

Dari pembahasan diatas sudah dijelaskan bahwa wanita dianggap lebih bahagia, dikarenakan peran sosial yang dilekatkan oleh masyarakat. Namun hal tersebut bukan suatu ukuran yang tepat, Menyimpulkan bahwa wanita dikatakan lebih bahagia dibandingkan pria. Karena ungkapan ekspresi emosi pada wanita terkait dengan pengasuhan yang lebih menekankan pada emosi yang positif. Hal tersebut tidak cukup menjadi varaibel penentu adanya perbedaan gender dalam memperoleh kebahagiaan.

Diener, Sandvik \& Larsen dan Fujita, Diener, \& Sandvik (Myers, Diener, 1995) menyatakan bahwa wanita dikatakan memiliki happiness yang lebih besar dibandingkan pria, apabila hanya diukur dari emosi positif. Padahal seseorang dikatakan bahagia tidak saja karena faktor emosi saja. Sebuah survey yang dilakukan oleh Inglehart menyatakan bahwa wanita dan pria rata-rata memiliki level kebahagiaan yang sama (Baumgardner dan Crothers,2010).

Sebuah survey yang dilakukan di 5 negara Asia oleh IPSOS Asia (2.378 responden usia 1850 tahun pada bulan Juli 2013), yakni China daratan, Hongkong, Malaysia, Korea Selatan dan Singapura melaporkan bahwa secara keseluruhan kebahagiaan warga diatas presentase $78 \%$. Alasan yang menjadikan warga Negara tersebut bahagia adalah hubungan dengan pasangan atau suami/ istri (45\%), kesehatan (42\%), dan kesehatan dari keluarga dan teman - teman (36\%). Sedangkan alasan ketidakbahagiaan adalah masalah financial (57\%), kesehatan (38\%), dan kondisi - kondisi hidup lainnya (36\%).

Dari data tersebut ditunjukkan bahwa wanita lebih bahagia dibandingkan pria. Dengan alasan kebahagiaan terbesar dikarenakan alasan kesehatan. Sedangkan hal yang paling membuat bahagia adalah keuangan (merata pada 5 negara tersebut). Di Singapura $26 \%$ wanita mereka merasa sangat bahagia bandingkan laki-laki, yang hanya mencapai $12 \%$. Sedangkan pada perasaan tidak terlalu bahagia, Pria Hongkong menduduki peringkat pertama dengan 24 \% (Ipsos, 2013). Senada dengan hasil survey IPSOS, bahwa wanita di Asia lebih bahagia dibandingkan kaum laki-laki. Penelitian di Jepang menyebutkan bahwa secara signifikan wanita di Jepang lebih bahagia dibandingkan pria (Tiefenbach, Tim \& Kohlbacher,Florian.2013). 
Sebuah penelitian yang dilakukan di Taiwan pada siswa lulusan SMA, menyebutkan bahwa perempuan lulusan SMA, lebih bahagia dibandingkan pria pada level yang sama. Namun sebaliknya, keadaan tersebut berbeda ketika di pendidikan tinggi dimana pria lebih bahagia dibandingkan wanita (LU dan Luo,.2010). Hal ini dikarenakan budaya Patriaki di Taiwan dan nilai gender tradisional yang memberikan tekanan pada wanita Taiwan yang berpendidikan tinggi.

Dari hasil penelitian yang menghubungkan antara kebahagiaan dan waktu kebahagiaan muncul disebutkan bahwa dari sisi usia, perempuan akan lebih berbahagia di usia muda dibandingkan laki laki, dan kebahagiaan mereka akan meningkat hingga akhir 20an hingga akhirnya berkurang sampai akhir 50 an, kebahagiaan perempuan mudah menghilang dan keseluruhan trendnya mengalami penurunan. Berbeda dengan laki - laki kebahagiannya yang meningkat hingga awal 30-an dan cenderung stabil hingga pension (Rousseau dan Jean-Benoit G, 2009). Apabila kebahagiaan dikaitkan dengan status pekerjaannya maka status pengangguran tidak memiliki efek pada kebahagiaan perempuan, dibandingkan laki - laki. Pekerjaan penuh waktu tidak berhubungan dengan kepuasan hidup laki-laki dan perempuan. Tetapi status pekerjaan paruh waktu meningkatkan kesejahteraan laki-laki,namun hal tersebut tidak berpengaruh pada perempuan (Rousseau dan Jean-Benoit G, 2009).

Dari hasil penelitian yang menghubungkan antara well being dengan cara berpikir lokal dan global menunjukkan bahwa wanita memiliki skor yang lebih tinggi apabila dibandingkan dengan pria, namun pria lebih memiliki level yang lebih tinggi pada cara berpikir global dibandingkan wanita (Gürel, 2009).

Sebuah penelitian yang dilakukan di Lucknow district, Uttar Pradesh, India ingin mengetahui Subjective happiness diantara orang tua diantara berbagai group menunjukkan bahwa tingkat kebahagiaan subjektif pada orang tua perempuan dan orang tua laki-laki di daerah urban adalah sama. Namun di area pedesaan, orang tua laki - laki lebih bahagia dibandingkan orang tua perempuan (Shukla, Pallavi \& U.V.Kiran, 2013:47). Apabila dilihat dari tipe keluarga, orang tua laki-laki memiliki kebahagiaan subjektif lebih tinggi apabila hidup di keluarga besar dibandingkan di keluarga kecil. Berbanding terbalik dengan orang tua perempuan yang lebih bahagia tinggal di keluarga kecil dibandingkan keluarga besar. Sedangkan kebahagiaan subjektif ditinjau dari status bekerja, menunjukkan bahwa orang tua yang tidak bekerja lebih bahagia dibandingkan yang bekerja (Shukla, Pallavi \& U.V.Kiran,2013).

Namun ada penelitian terbaru pada tahun 2014 (Chandiramani ,Komal) menyebutkan bahwa terdapat signifikansi diantara dewasa perempuan dan laki - laki pada keseluruhan pengukuran SWB. Bahwa rata-rata group laki-laki memiliki nilai SWB yang lebih tinggi dibandingkan perempuan. Menurut Lippa (Chandiramani ,Komal. 2014) Perbedaan ini dikarenakan adanya perbedaan seks secara universal. Laporan UNDP pada tahun 2002 (Chandiramani,Komal, 2014) menyebutkan bahwa perbedaan gender yaitu perbedaan kondisi kehidupan, adanya ketersediaan kesempatan dan sumber kreasi yang tidak adil diantara wanita dan pria di banyak kebudayaan yang akhirnya menjafikan perolehan SWB pada wanita menjadi rendah. Namun dalam penelitian Wood dan Rhodes (Chandiramani,Komal, 2014) wanita disebutkan memiliki hubungan personal yang lebih baik dibandungkan pria yang membuatnya bahagia dan memiliki kepuasan hidup dibandingkan pria.

\section{Paradoks Tentang Kebahagiaan Wanita}

Wanita yang mudah mengungkapkan emosi baik positif maupun negatif dianggap memiliki kesulitan untuk mencapai kebahagiaan. Berbeda dengan pria yang cenderung tidak terlalu banyak mengungkapkan emosinya, dianggap lebih mudah mencapai kebahagiaan. Padahal secara umum pria dan wanita memiliki kesempatan yang sama untuk dapat mencapai kebahagiaan dan kepuasan hidup secara keseluruhan (Baumgardner dan Crothers, 2010).

Kebahagiaan wanita dari konteks budaya, menempatkan wanita sebagai sosok yang dituntut memiliki peranan sebagai pengasuh sehingga diperlukan kemampuan untuk menunjukkan emosi. Di sisi lain ada kajian yang mengatakan bahwa dalam peran gendernya wanita dituntut untuk tunduk pada budaya patriaki sehingga tidak terlalu banyak memiliki kesempatan untuk menunjukkan diri dan memajukan diri. Stereotipe gender pada suatu budaya menjadikan masih kuatnya pemikiran tentang adanya perbedaan emosi pada pria dan wanita (Baumgardner dan Crothers, 2010).

Namun seiring dengan peningkatan pendidikan yang bahkan melampaui pria, perkembangan alatalat berteknologi tinggi yang mulai membebaskan wanita dari pekerjaan yang membosankan, dan kebebasan wanita untuk memilih antara keluarga dan pekerjaan, perubahan tersebut menaikkan nilai tawar perempuan dalam rumah tangga dan 
meningkatkan kesempatan mereka diluar pekerjaan (Stevenson dan Wolfers, 2009).

\section{KESIMPULAN}

Perdebatan tentang mana yang lebih bahagia antara pria dan wanita, menimbulkan sebuah polemik untuk benar-benar menetapkan mana yang paling bahagia diantara keduanya. Banyak penelitian yang mendukung bahwa kebahagiaan adalah milik wanita karena wanita lebih mampu mengungkapkannya dibandingkan pria. Namun di sisi lain wanita lebih mudah mengalami masalah yang terkait dengan hambatan emosional.

Pria dan wanita mengalami cara pengasuhan yang berbeda (Wood, Wendy, Rhodes dan Whelan, 1989), cara berpikir (Gürel,2009), fungsi biologis, dan lingkungan yang berbeda (Wood, Wendy, Rhodes dan Whelan, 1989). Sehingga memiliki cara yang berbeda dalam mencapai kebahagiaannya.

Kecenderungan wanita lebih bahagia dan memiliki kepuasan hidup dibandingkan pria memiliki hubungan yang sangat kecil (Wood, Wendy, Rhodes dan Whelan, 1989). Sehingga dapat disimpulkan bahwa keduanya, baik pria maupun wanita memiliki sama-sama bahagia, dengan kombinasi antara kelebihan dan kelemahannya (Baumgardner, Crothers, 2010:89).

\section{DAFTAR PUSTAKA}

Baumgardner, Steve.R. \& Crothers, Marie.K. (2010). Positive psychology. New Jersey : Pearson Education, Inc

Chandiramani, Komal. (2014).Locus of control and subjective wellbeing: examining gender differences. Indian Journal of Health and Wellbeing 2014, 5(3), 325-329

Compton, William .C. \& Hoffaman, Edward. (2013). Positive psychology: the science of happiness and flourishing, second edition. Belmont: Wadsworth

Gürel, Nergis Ayșe. (2009). Effects of thinking styles and gender on psychological well being. (Thesis, The Graduate School of Social Sciences of Middle East Technical University,Turki)

Hefferon, Kate \& Ilona Boniwell.(2011). Positive psychology theory, research and applications. New York: McGraw-Hill

\section{Kritik}

Pemberian justifikasi yang mendasarkan pada budaya setempat untuk menentukan kebahagiaan ada pada satu peran gender harusnya dikesampingkan, karena sebuah penelitian empiris harus dapat digeneralisasikan pada latar belakang yang lain. Wanita dan pria, selain memiliki perbedaan dalam biologis, namun juga pada hal yang lain. Apabila peran gender atau gender role dipaksakan untuk ditentukan mana yang terbaik, selamanya akan mengalami kesulitan. Karena peran gender antara pria dan wanita adalah berbeda sama sekali.

\section{Saran}

Perlu dilakukan penelitian yang menemukan yang mampu menjembatani aspek yang membuat kebahagiaan pria dan wanita pada taraf yang sama. Walaupun pada beberapa penelitian terdapat perbedaan kebahagiaan antara pria dan wanita, pada taraf yang sangat kecil.

Perbandingan aspek yang menimbulkan kebahagiaan pada pria dan wanita bisa saja berbeda,namun pada dasarnya keduanya samasama dapat memperoleh kebahagiaan. Berkaitan dengan adanya pardoks yang menyebutkan wanita memilki kecenderungan untuk mengalami gangguan emosi, perlu dicari apakah memang dikarenakan wanita yang terlalu ekspresif dalam menunjukkan emosinya ataukah memang pria yang kurang bisa menunjukkan emosi. Tentu aspek biologis juga dapat mempengaruhinya.

Ipsos. (2013). What makes asians happy. Press Release.19 November 2013.

LU, Luo.(2010). Who is happy in Taiwan? the demographic classification of the happy person. Psychologia,2010,53,55-67

Myers, David G.(2000). The funds, friends, and faith of happy people. Journal of the American Psychological Association. January 2000 Volume 55 Number 1 (5-14)

Myers, David G, Diener,Ed.(1995). Who is happy. Psychological Science. Vol.6, No.1, January 1995

Rousseau, Jean-Benoit G.(2009). Time for happiness. Laporan Penelitian.Montreal: Social Sciences and Humanities Research Council of Canada and the Fond de Recherche sur la Societ' e et la Culture du Qu' ebec 
Seligman, Martin .E, Csikszenimihalyi, Mihalyi. (2000). Positive psychology an introduction. Journal of the American Psychological Association. January 2000 Volume 55 Number 1 (5-14)

Seligman, Martin.(Oktober,2010). Flourish : Positif Psychology and Positive Intervention. Makalah yang dipresentasikan pada The Tanner Lectures on Human Values, The University of Michigan

Shukla, Pallavi \& U.V.Kiran.(2013). Subjective happiness among the elderly across various groups. IOSR Journal Of Humanities And Social Science (IOSR-JHSS) Volume 13, Issue 6 (Jul - Aug. 2013), PP 46-49

Stevenson, Wolfers. (2009). The Paradox of Declining Female Happiness. Laporan penelitian. Federal Reserve Bank Of San Fransisco
Synder, Lopez, 2002. Handbook of Positive Psychology. New York : Oxford University Press

Tiefenbach, Tim \& Kohlbacher,Florian.2013. Happiness and Life Satisfaction in Japan by Gender and Age. Laporan Penelitian. Tokyo:German Institute for Japanese Studies (DIJ)

Waterman, Alan. 1993. Two conceptions of happiness: contrasts of personal expressiveness (eudaimonia) and hedonic enjoyment. Journal of Personality and Social Psychology 1993, Vol.64. No.4. 678-69

Wood, Wendy, Rhodes, Whelan,M, 1989. Sex differences in positive well-being: a consideration of emotional style and marital status. Psychological Bulletin. 1989, Vol. 106, No. 2, 249-26 